\title{
Adaptasi Penghuni terhadap Perubahan Ruang Domestik menjadi Ruang Usaha akibat Pandemi COVID19
}

\author{
Wiyatiningsih \\ Universitas Kristen Duta Wacana, Jl. dr. Wahidin Sudirohusodo 5-25 Yogyakarta 55224, Indonesia \\ Telp/ Handphone 087738020584 \\ Email: wiyatiningsih@staff.ukdw.ac.id
}

\begin{abstract}
INFORMASI ARTIKEL
Abstract: The study purposes to find out adaptation forms of inhabitants to the change of domestic to commercial spaces caused by economic innovation during pandemic. The study implements a qualitative method with two study cases of orchid houses in Cangkringan SubDistrict. Analysis was done to the mix-used spaces and form of inhabitants's adaptation. The study results show that online lifestyle during pandemic causes the comercializing of houses (Home Based Enterprises). The change is responded through cultural, physiological and morphological adaptation categorized as extending adaptation. The health protocol is merely adapted through the arrangement of guest's welcoming room in the outdoor space.
\end{abstract}

Keywords: adaptation; COVID-19 pandemic; Home Based Enterprises; mix-used space; online lifestyle; orchid.

\begin{abstract}
Abstrak: Penelitian ini bertujuan untuk menemukan pola adaptasi penghuni terhadap perubahan ruang domestik menjadi ruang produksi akibat inovasi ekonomi masa pandemi. Penelitian ini menerapkan metode kualitatif dengan Studi Kasus terhadap dua rumah usaha tanaman anggrek di Kecamatan Cangkringan. Analisis dilakukan terhadap perubahan ruang mix-used dan bentuk adaptasi penghuni. Hasil penelitian menunjukkan bahwa gaya hidup online masa pandemi berdampak pada perubahan rumah sebagai ruang usaha (Home Based Enterprises). Perubahan fungsi komersial rumah direspon melalui adaptasi kultural, fisiologi dan morfologi yang digolongkan dalam tipe adaptasi perluasan (extending). Adaptasi terhadap protokol kesehatan dilakukan sebatas penataan ruang tamu di ruang luar.
\end{abstract}

Kata Kunci: adaptasi; anggrek; gaya hidup online; Home Based Enterprises; pandemi COVID-19; ruang mix-used;

\section{Article history:}

Received; 2021-06-01

Revised; 2021-07-01

Accepted; 2021-09-01

\section{PENDAHULUAN \\ Perubahan Gaya Hidup Online selama Pandemi COVID-19}

World Health Organization (WHO) pada tanggal 11 Maret 2020 menetapkan wabah COVID-19 sebagai pandemi global. Penetapan status ini disebabkan oleh penyebaran virus yang cepat dan meluas sampai jauh dari pusatnya (Elvina, 2020). Salah satu cara yang digunakan oleh WHO untuk mencegah penyebaran virus corona adalah dengan menetapkan social distancing. Dokumen resmi WHO tanggal 20 Maret 2020 menyebutkan perubahan istilah social distancing menjadi physical distancing. Pemberlakukan physical distancing selama masa pandemi COVID-19 berdampak pada perubahan pola hidup dan ruang yang digunakan, termasuk rumah tinggal.

Physical distancing diikuti dengan instruksi "stay at home" yang berdampak pada pemberlakukan "work from home" atau WfH. Pembatasan aktivitas manusia selama masa pandemi menekan sektor ekonomi. Menteri Keuangan RI Sri Mulyani Indrawati menyebutkan bahwa terdapat empat sektor yang paling tertekan oleh pandemi COVID-19, yaitu rumah tangga, UMKM, korporasi dan keuangan (Saubani, 2020). Sebagian masyarakat yang terdampak secara finasial berusaha untuk mendapatkan sumber penghasilan baru. 
Situasi "stay at home" menjadi peluang bagi usaha belanja online dan jasa pengantaran. CNN Indonesia menyebutkan bahwa gaya hidup dan bisnis "stay at home" melahirkan pola hidup baru "stay at home economy" yang bertumpu pada e-commerce dan jasa logistic (Septalisma, 2020).

Perubahan gaya hidup online dan tekanan ekonomi akibat pandemi COVID-19 mendorong sebagian masyarakat untuk mengelola usaha yang bisa dilakukan di rumah. Penambahan fungsi usaha di rumah tersebut merubah pola ruang rumah tinggal menjadi ruang multi fungsi (mixed-use) secara spontan. Pemanfaat rumah tinggal sebagai ruang usaha dikenal sebagai Home Based Enterprises (HBEs) yang umum terjadi di Indonesia dan negara berkembang secara luas. Rumah tidak hanya sebagai tempat untuk reproduksi sosial, tetapi juga tempat untuk produksi. Rumah tidak hanya sebagai hunian tempat berlindung, namun lebih dari sekedar bentuk fisik terutama tempat untuk menghasilkan pendapatan (Marsoyo, 2012). Berdasarkan latar belakang tersebut, penelitian ini bertujuan untuk menemukan pola perubahan ruang domestik menjadi ruang mixed-use dan pola adaptasi penghuni terhadap perubahan ruang tersebut.

\section{Prinsip Adaptasi Spasial}

Adaptasi berasal dari bahasa Latin "adaptation" yang menunjukkan sebuah aksi penyelarasan (adapting) dalam arti menyesuaikan (adjusting) (Simonet, 2010). "Adaptation" mengacu pada penyesuaian sistem ekologis, sosial atau ekonomi dalam merespon rangsangan iklim terkini atau yang diharapkan dan akibatnya. Adaptasi mengacu pada proses, tindakan atau hasil dalam sebuah sistem (rumah tangga, komunitas, kelompok, sektor, wilayah, negara) sebagai cara mengatasi sistem yang lebih baik, mengelola atau menyesuaikan terhadap beberapa perubahan kondisi, stres, bahaya, risiko atau peluang (Smith \& Wandel, 2006).

Gifford (1987) dalam Purnamasari (2013) menyebutkan bahwa adaptasi dipengaruhi oleh aktivitas penghuni dalam lingkungan hunian ditambah susunan ruang dalam lingkungan itu sendiri. Mengutip dari Soemarwoto (1991), Purnamasari (2013) menyebutkan tiga proses adaptasi, yaitu:

1) Sikap atau tingkah laku (adaptasi kultural).

2) Fisiologi (adaptasi fungsi ruang),

3) Morfologi (adaptasi bentuk ruang)

Kriteria tiga proses adaptasi di atas akan dipergunakan penulis untuk menganalisis adaptasi pada studi kasus penelitian ini.

Pengertian adaptasi arsitektur dan lanskap pada masa pandemi COVID-19 dijabarkan oleh Purwono (2020) sebagai perubahan kehidupan sosial akibat protokol kesehatan sesuai instruksi WHO terhadap pengaturan ruang berdasarkan dimensi dan urutan ruang, material arsitektur, aspek softscape pada lansekap dan fisika bangunan.

\section{Adaptasi pada Home Based Enterprises (HBEs)}

Home based Enterprises (HBEs) merupakan penggabungan fungsi rumah sebagai tempat berlindung sekaligus ruang usaha untuk menghasilkan pendapatan. Penggabungan fungsi reproduksi dan produksi di dalam rumah mengakibatkan terjadinya adaptasi meruang (Marsoyo, 2012). Mengacu pada Ching (1987), Marsoyo (2012) menyebutkan dua istilah adaptasi, yaitu "tight fit" dan "loose fit". Kondisi "tight fit" terjadi jika perabotan dan perlengkapan ditempatkan pada posisi tetap dan dengan konfigurasi ruang tertentu. Sedangkan pada kondisi "loose fit" perabotan dapat dengan mudah dipasang secara fleksibel menurut kebutuhan pengguna.

Marsoyo (2012) membedakan tiga kategori adaptasi ruang pada Home Based Enterprises, yaitu: berbagi (sharing), menambahkan (extending) dan bergantian (shifting). 
Adaptasi sharing terjadi pada ruang dan perabot yang difungsikan bersama untuk kegiatan domestik dan usaha. Adaptasi extending dilakukan melalui penambahan ruang yang khusus dipergunakan sebagai ruang usaha. Adaptasi shifting terjadi ketika ruang dan perabot dipergunakan secara bergantian, karena keterbatasan ruang di dalam rumah.

\section{Kesehatan Rumah sebagai Penangkal COVID-19}

Rumah sehat adalah tempat perlindungan yang mendukung kesejahteraan fisik, mental dan sosial yang utuh (World Health Organization, 2018). Kesehatan fisik rumah sangat erat hubungannya dengan kondisi fisik rumah. Rasa nyaman diwujudkan dengan kecukupan pencahayaan, pengaliran udara yang mampu memenuhi kebutuhan oksigen, dan kelembaban di dalam ruang yang sesuai dengan suhu tubuh penghuninya, serta kebutuhan ruang gerak yang cukup (Sabaruddin, Hartini, \& Hermawan, 2011).

Menurut Kepmen Kimpraswil Nomor 403/KPTS/M/2002 rumah layak huni harus memenuhi luas minimal $36 \mathrm{~m}^{2}$ yang dimanfaatkan oleh maksimal 4 jiwa. Jika melebihi 4 jiwa dalam rumah, maka harus ditambahkan $9 \mathrm{~m}^{2}$ setiap jiwa (Sabaruddin et all, 2011:11). Mengutip dari Chairul Amal Septono, Pengurus Himpunan Desainer Interior Indonesia, Muhammad Shiddiq (2020) menyatakan bahwa pengendalian tata cahaya dan aliran udara di dalam rumah merupakan hal yang penting untuk dilakukan pada masa pandemi. Hal ini sejalan dengan Peraturan Menteri Kesehatan RI No. 1077/Menkes/PER/V/2011 tentang Pedoman Penyehatan Udara dalam Rumah.

\section{METODE PENELITIAN}

Penelitian ini menerapkan metode penelitian kualitatif dengan pendekatan Studi Kasus, yaitu serangkaian kegiatan ilmiah yang dilakukan secara intensif, terinci dan mendalam tentang suatu program, peristiwa, dan aktivitas, baik pada tingkat perorangan, sekelompok orang, lembaga, atau organisasi untuk memperoleh pengetahuan mendalam tentang peristiwa tersebut (Rahardjo, 2017). Penelitian dilakukan terhadap 2 studi kasus yang dipilih berdasarkan jenis usaha yang mewakili tren bisnis pada masa pandemi COVID-19 dan kedekatan lokasi, yaitu di daerah Kecamatan Cangkringan, Kabupaten Sleman (Gambar 1).

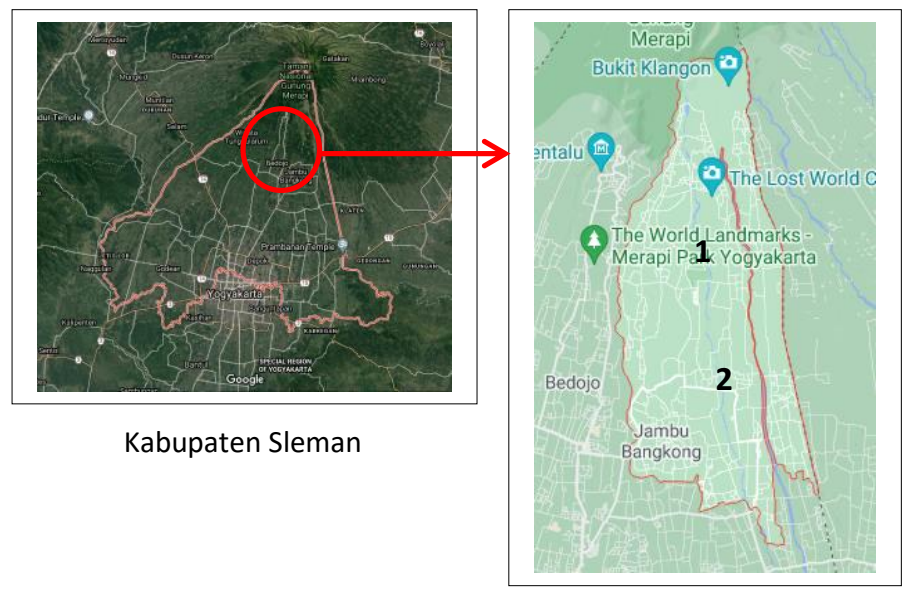

\section{Gambar 1. Lokasi Studi Kasus Penelitian di Kecamatan Cangkringan, Kabupaten Sleman}

Sumber: google maps, 2020

Perubahan ruang dan adaptasi penghuni terhadap perubahan ruang pada kedua studi kasus dianalisi menggunakan prinsip adaptasi spasial yang mencakup 3 aspek, yaitu: adaptasi kultural, fisiologi dan morfologi. Adaptasi terhadap perubahan rumah sebagai ruang usaha 
dianalisis menggunakan tiplogi adaptasi pada HBEs. Adaptasi terhadap protokol kesehatan masa pandemi COVID-19 dinilai dari standar kesehatan rumah.

\section{HASIL DAN PEMBAHASAN}

\section{Pengembangan Usaha selama Pandemi COVID-19}

Kasus 1 (Sekar Sharon Kebun) dan Kasus 2 (Mellamel Mel) mengembangkan usaha tanaman anggrek secara bertahap. Pada awal masa WfH kedua kasus menjalankan bisnis kuliner secara online pada skala lokal. Bersamaan dengan usaha kuliner, keduanya menjalankan bisnis tanaman anggrek. Namun, Kasus 1 sudah menjalankan usaha tanaman hias termasuk anggrek sejak sebelum wabah virus corona. Berkembangnya bisnis tanaman anggrek pada masa pandemi dipengaruhi oleh tren hobi merawat tanaman hias. Usaha tanaman anggrek berkembang pesat, sehingga diperlukan penambahan ruang untuk budidaya dan display tanaman anggrek. Penambahan ruang usaha ini dilakukan di ruang luar/halaman rumah, dengan membangun rumah anggrek.

\section{Strategi Pemasaran masa Pandemi}

Kedua studi kasus memasarkan produk tanaman anggrek melalui media sosial, seperti Marketplace Facebook, Whatsapp dan Instagram. Strategi pemasaran juga dilakukan melalui sistem reseller, baik untuk skala kecil maupun besar. Metode pemasaran online berdampak pada pola aktivitas pedagang dan ruang yang dipergunakan untuk packaging dan pengiriman pesanan pembeli.
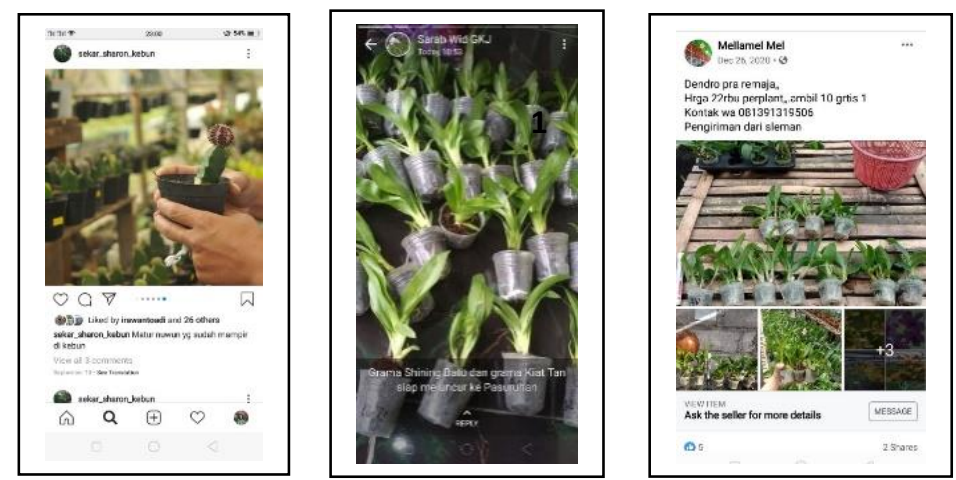

\section{Gambar 2. Contoh Pemasaran Tanaman Anggrek melalui Media Sosial \\ Sumber: Instagram, Whatsapp \& Facebook, 2020}

Media online memudahkan orang untuk mengakses sebuah tempat. Teknologi ini dimanfaatkan oleh Kasus 1 dengan menandai lokasinya pada google maps. Penandaan lokasi pada peta ini berdampak signifikan terhadap peningkatan jumlah pengunjung terutama pada akhir pekan.

\section{Pemanfaatan Rumah sebagai Ruang Usaha}

Perkembangan jenis usaha berpengaruh terhadap pola pemanfaatan ruang di dalam rumah. Pada kedua studi kasus terdapat perubahan pola penggunaan ruang di dalam rumah sebelum dan masa pandemi. Pada Kasus 1, pemanfaatan fungsi rumah sebagai ruang usaha semakin bertambah pada masa pandemi. Ruang privat seperti ruang keluarga dan dapur difungsikan juga sebagai ruang pengolahan makanan yang dijual berdasarkan pesanan (Gambar 3). Penambahan fungsi usaha mengurangi batas ruang privat, terutama akibat kehadiran langsung pelanggan ke dalam rumah. 


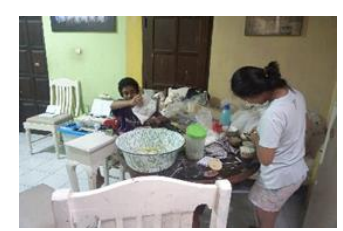

1 Ruang produksi makanan di r. keluarga
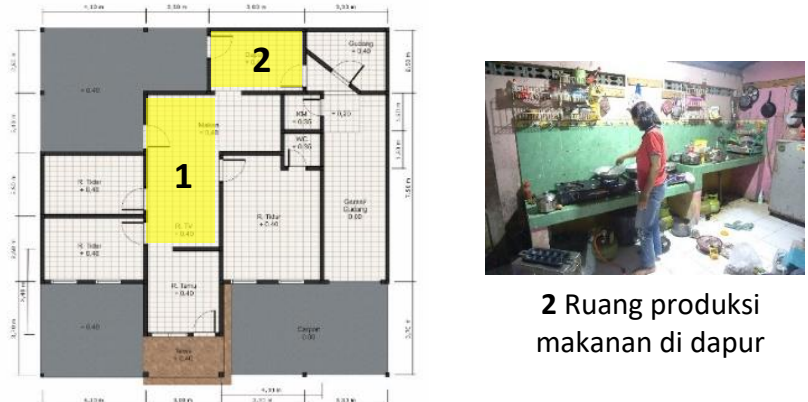

2 Ruang produksi makanan di dapur

\section{Gambar 3. Penambahan Fungsi Usaha di Ruang Privat (Kasus 1)}

Sumber: Wiyatiningsih, 2020

Ketika bisnis kuliner sudah berjalan, Kasus 1 menghidupkan kembali kebun tanaman hiasnya yang kurang terawat sejak bisnis dekorasi dan persewaan taman terhenti karena pandemi. Pengembangan dilakukan dengan menjadikan tanaman anggrek sebagai produk unggulan. Pengembangan usaha ini berdampak pada perluasan ruang usaha di halaman rumah yang dijadikan sebagai rumah anggrek dan tanaman hias (Gambar 4).
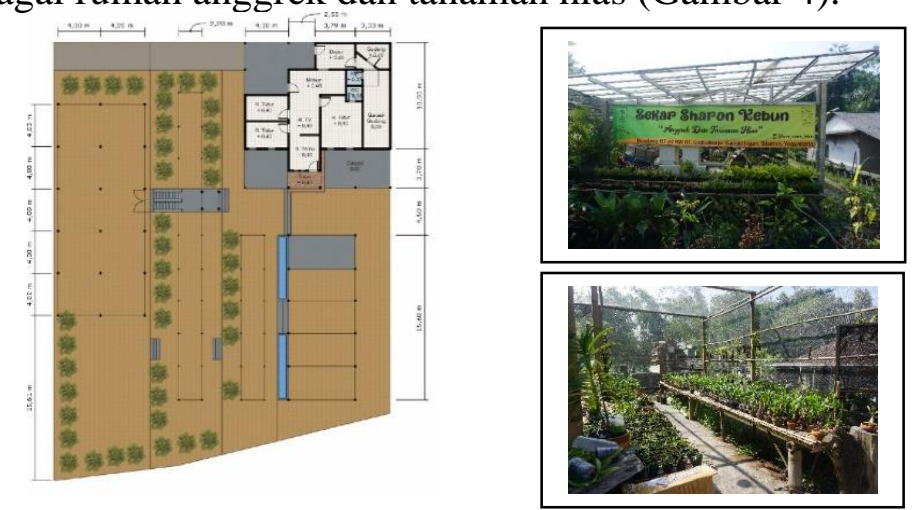

\section{Gambar 4. Halaman Rumah sebagai Rumah Anggrek (Kasus 1) \\ Sumber: Wiyatiningsih, 2020}

Pada Kasus 2 tidak ada kejelasan batas antara kegiatan domestik dan produksi di ruang privat. Hal ini disebabkan oleh keterbatasn ruang di dalam rumah. Kegiatan memasak dan pengemasan makanan menggunakan ruang yang ada secara bergantian dengan kegiatan rutin harian (Gambar 4).

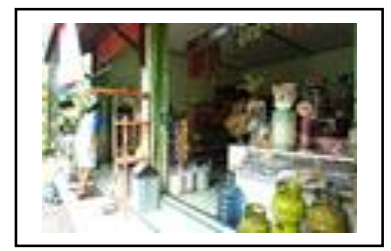

1 Ruang produksi makanan di dapur
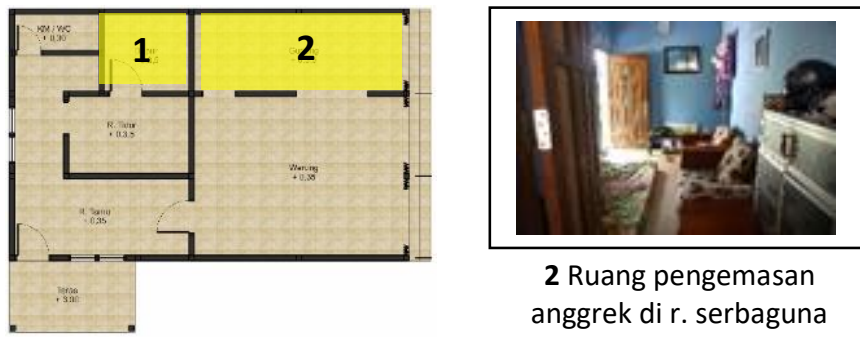

2 Ruang pengemasan anggrek di r. serbaguna

\section{Gambar 4. Penambahan Ruang Usaha di Ruang Privat (Kasus 2)}

Sumber: Wiyatiningsih, 2020

Seiring dengan perkembangan tren pola hidup WfH, usaha lebih difokuskan pada tanaman anggrek daripada kuliner. Untuk mewadahi aktivitas usaha ini dibangun rumah anggrek di halaman rumah. Rumah anggrek ini berfungsi sebagai ruang pemeliharaan sekaligus ruang display karena berada di tepi jalan besar (Gambar 5). 

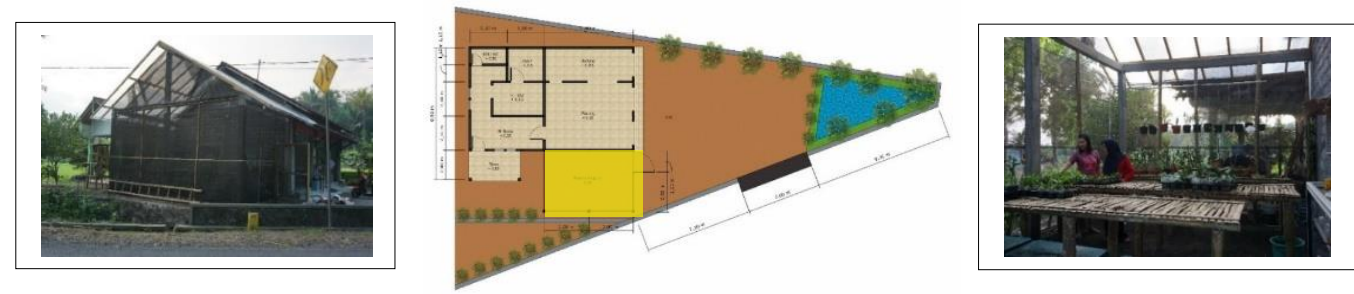

\section{Gambar 5. Halaman Rumah sebagai Rumah Anggrek (Kasus 2) \\ Sumber: Wiyatiningsih, 2020}

\section{Penyesuaian terhadap Tatanan Baru}

Upaya yang dilakukan untuk merespon protokol kesehatan pencegahan virus corona dilakukan oleh Kasus 1 melalui penyediaan wastafel, penataan kursi tamu yang berjarak, serta ketertiban penghuni rumah untuk menggunakan masker terutama ketika ada pelanggan yang datang ke kebun.

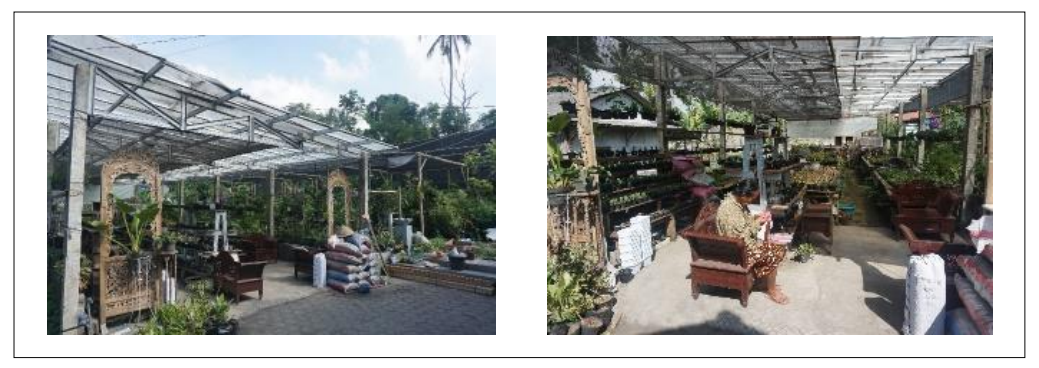

\section{Gambar 6. Adaptasi terhadap Protokol Kesehatan (Kasus 1) \\ Sumber: Wiyatiningsih, 2020}

Seperti terlihat pada Gambar 6, ruang tamu yang diletakkan di kebun lebih sering dipergunakan untuk menerima tamu daripada di dalam rumah. Peletakan ruang tamu di area terbuka merupakan upaya untuk mendapatkan udara yang lebih sehat bagi penghuni maupun tamu. Kasus 2 belum menerapkan protokol kesehatan pada tata ruang maupun penyediaan wastafel untuk mencuci tangan dan penggunaan masker ketika menemui tamu. Ditinjau dari ukuran ruang, protokol jaga jarak sepertinya belum dapat dipenuhi pada Kasus 2 karena keterbatasan luasan ruang. Tidak dipenuhinya protokol mencuci tangan dan pemakaian masker kemungkinan disebabkan oleh sedikitnya pengunjung yang datang ke rumah usaha ini. Tamu yang datang sebagian besar saudara atau tetangga di sekitar rumah.

\section{Adaptasi Spasial terhadap Perubahan Fungsi Rumah menjadi Ruang Usaha}

Ditinjau dari tipe adaptasi spasial menurut Soemarwoto dalam Purnamasari (2013), penyesuaian meruang yang terjadi pada kedua studi kasus mencakup adaptasi kultural, fisiologi dan morfologi. Bentuk adaptasi tersebut ditunjukkan melalui Tabel 1 berikut ini:

Tabel 1. Adaptasi Spasial terhadap Perubahan Fungsi Rumah menjadi Ruang Usaha

\begin{tabular}{clcl}
\hline & Adaptasi Kultural & Adaptasi Fisiologi & \multicolumn{1}{c}{ Adaptasi Morfologi } \\
\hline Kasus 1 & Pengembangan ragam & - Ruang mix-used di & - Tambahan rumah \\
& usaha: & dalam rumah & anggrek \& tanaman hias \\
& - Dekorasi \& tanaman & - Penambahan rumah & semi terbuka di halaman \\
& hias & anggrek \& tanaman & rumah \\
& - Kuliner & hias di halaman rumah & - Pemindahan aktifitas \\
& - Tanaman anggrek & - Ruang tamu di luar & bisnis di kebun \\
& Pemasaran online dan & rumah & \\
& offline & & \\
\hline
\end{tabular}




\begin{tabular}{llll}
\hline \multicolumn{1}{c}{ Adaptasi Kultural } & Adaptasi Fisiologi & \multicolumn{1}{c}{ Adaptasi Morfologi } \\
\hline Kasus 2 & Pengembangan ragam & - Ruang mix-used di & - Tambahan rumah \\
& usaha: & dalam rumah \& & anggrek semi terbuka di \\
& - Warung kelontong & warung & halaman rumah \\
- Kuliner & - Penambahan rumah & - Perubahan akses masuk \\
& - Tanaman anggrek & anggrek di halaman & rumah \\
& $\begin{array}{l}\text { Sebagian besar } \\
\text { pemasaran } \text { online }\end{array}$ & rumah & \\
& & \\
\hline
\end{tabular}

Seperti terlihat pada Tabel 1, adaptasi kultural yang terjadi pada kedua studi kasus berupa pengembangan ragam usaha yang dipengaruhi oleh perubahan gaya hidup offline menjadi online dan tren hobi yang berkembang selama pandemi. Adaptasi fisiologi dari kedua studi kasus terjadi secara bertahap menyesuaikan perkembangan jenis usaha. Pada tahap awal terjadi penggabungan fungsi ruang domestik dan produksi (mix-used) di dalam rumah. Pengembangan ruang usaha di luar rumah menggeser sebagian aktivitas privat ke kebun. Adaptasi morfologi berupa penambahan bangunan semi terbuka sebagai ruang budidaya dan display tanaman anggrek. Rumah anggrek menjadi pusat aktivitas bisnis dari kedua studi kasus. Penambahan rumah anggrek ini merubah akses masuk ke rumah utama pada Kasus 2.

\section{Tipologi Home Based Entreprises}

Ditinjau dari kategori adaptasi ruang menurut Ching (1987) dalam Marsoyo (2012), perubahan ruang akibat pengembangan usaha pada kedua studi kasus tergolong sebagai adaptasi " $t$ ight fit". Tipe adaptasi ruang ini ditandai dengan pembuatan struktur bangunan dan perabot yang menetap dan tidak berubah-ubah posisi maupun bentuknya.

Berdasarkan pengelompokan Marsoyo (2012) tentang adaptasi pada rumah yang dipergunakan sebagai usaha (Home Based Enterprises), adaptasi pada kedua studi kasus tergolong sebagai adaptasi menambahkan (extending) untuk fungsi utama dan berbagi (sharing) untuk fungsi pendukung. Adaptasi extending terlihat pada penambahan rumah anggrek yang dipergunakan sebagai ruang usaha yang tidak bercampur dengan ruang domestik. Adaptasi sharing terjadi pada ruang pendukung untuk kegiatan penyimpanan dan pengemasan yang dilakukan di area garasi dan gudang.

Kasus 1
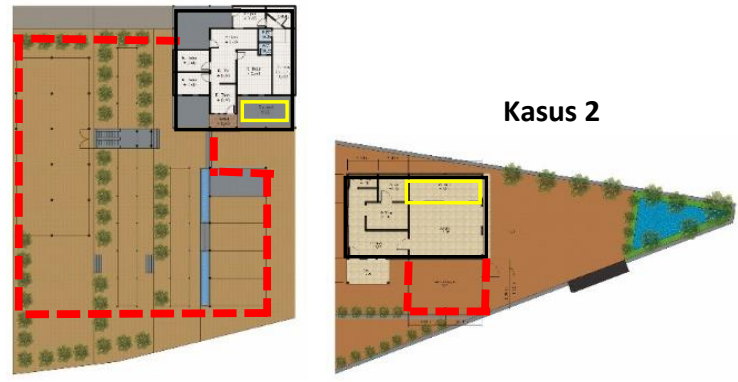

\section{Gambar 7. Adaptasi Extending dan Sharing pada Studi Kasus \\ Sumber: Wiyatiningsih, 2020}

Seperti terlihat pada Gambar 7, kedua studi kasus melakukan penambahan rumah anggrek di halaman luar rumah dengan skala yang berbeda. Karena keterbatasan luas lahan, rumah anggrek pada Kasus 2 hanya berukuran $24 \mathrm{~m}^{2}$, jauh lebih kecil dibandingkan dengan rumah anggrek pada Kasus 1 yang memiliki luas sekitar $400 \mathrm{~m}^{2}$. Meski demikian, keduanya memiliki fungsi yang sama, yaitu sebagai ruang budidaya dan display tanaman anggrek. 
Adaptasi sharing terjadi pada fungsi pendukung, yaitu ruang penyimpanan dan pengemasan produk tanaman. Pada Kasus 1 ruang sharing terjadi di teras dan garasi, sedangkan pada Kasus 2 di gudang warung.

\section{Upaya mencapai Kenyamanan Kesehatan}

Berdasarkan standar kenyaman ruang pada masa pandemi yang ditinjau dari pengertian kenyamanan kesehatan ruang menurut Sabaruddin et al. (2011:1) dan Chairul tentang pedoman penyehatan udara di dalam rumah, kecukupan pencahayaan, pengaliran udara dan kelembaban di dalam ruang, serta kebutuhan ruang gerak yang cukup (Muhammad Shiddiq, 2020), kedua studi kasus belum memperhatikan aspek kenyamanan kesehatan terutama di dalam rumah yang masih multi fungsi dan belum memperhatikan kualitas pencahayaan dan penghawaan. Ditinjau dari standar kenyamanan kesehatan menurut Kepmen Kimpraswil Nomor 403/KPTS/M/2002 tentang luas bangunan minimal $36 \mathrm{~m}^{2}$ yang dimanfaatkan oleh maksimal 4 jiwa, Kasus 1 lebih memenuhi standar daripada Kasus 2. Selain itu, Kasus 1 juga lebih memperhatikan protokol kesehatan pada penataan ruang usahanya di area kebun.

\section{SIMPULAN DAN SARAN}

Masa pandemi COVID-19 merubah pola hidup masyarakat yang berdampak pada perubahan aktivitas ekonomi dari kedua studi kasus. Aktivitas ekonomi yang dilakukan di rumah memaksa penghuninya untuk beradaptasi terhadap perubahan ruang tersebut. Dua studi kasus penelitian ini (Sekar Sharon Kebun dan Mellamel Mel) memiliki kemiripan jenis pengembangan usaha, yaitu tanaman anggrek. Jenis usaha ini menjadi populer selama masa pandemi yang ditandai dengan peningkatan usaha dari kedua kasus yang cukup signifikan. Adaptasi penghuni terhadap perubahan fungsi rumah menjadi ruang usaha ditinjau dari tiga aspek adaptasi spasial meliputi: sikap dan tingkah laku (adaptasi kultural), fisiologi (adaptasi fungsi ruang), dan morfologi (adaptasi bentuk ruang). Adaptasi kultural pada kedua studi kasus berlangsung secara bertahap seiring dengan perkembangan situasi selama pandemi. Perubahan pola hidup work from home yang berbasis online berpengaruh terhadap jenis usaha dan metode pemasarannya. Jangkauan pasar/pelanggan bertambah yang kemudian berpengaruh terhadap metode penyediaan dan pengiriman barang dagangan.

Adaptasi fungsi ruang dilakukan oleh kedua studi kasus untuk mewadahi pengembangan aktivitas ekonomi di rumah. Budidaya dan display tanaman anggrek ditempatkan di rumah anggrek yang dibangun di halaman luar rumah. Tingginya aktivitas penghuni di rumah anggrek merubah pola penggunaan ruang di dalam rumah. Penerimaan tamu cenderung dilakukan secara informal di area rumah anggrek, sehingga ruang di dalam rumah menjadi lebih privat dibandingkan sebelumnya. Adaptasi morfologi pada kedua studi kasus ditunjukkan melalui perubahan ruang luar/halaman rumah sebagai rumah anggrek yang menjadi ruang usaha. Penambahan ruang ini menyebabkan perubahan bentuk rumah dan akses masuk ke dalamnya. Adaptasi kedua studi kasus ditinjau dari dari aspek Home Based Enterprises menunjukan tipe adaptasi ruang menetap "tight fit" dengan adaptasi extending pada ruang usaha dan sharing pada ruang pendukung. Adaptasi terhadap kenyamanan kesehatan masa pandemi COVID-19 hanya terjadi pada Kasus 1 yang memiliki luas lahan dan kapasitas kebun yang lebih besar.

Mengingat pembatasan jarak fisik selama masa pandemi, maka proses pengumpulan data di lapangan mengalami kendala. Untuk memperdalam pembahasan perlu dilakukan penelitian terhadap kasus sejenis di lokasi yang berbeda. Hal ini diperlukan untuk memperluas dimensi pengetahuan tentang pola adaptasi terhadap kenyamanan kesehatan selama masa pandemi COVID-19. Penelitian tentang aspek kenyamanan kesehatan perlu dilakukan dengan pengukuran kuantitatif untuk mendapatkan standar kenyamanan yang 
terukur. Untuk itu, pelibatan bidang fisika bangunan dalam penelitian akan sangat bermanfaat untuk meningkatkan kualitas penelitian ini.

\section{DAFTAR RUJUKAN}

Sabaruddin, A.; Hartini; \& Hermawan, Y. 2011. Modul Rumah Sehat. Bandung: Kementrian Pekerjaan Umum.

Soemarwoto. 1991. Ekologi, Lingkungan Hidup dan Pembangunan. Jakarta: Djambatan.

World Health Organization. 2018. WHO Housing and Health Guidelines. Switzerland: World Health Organization.

Purnamasari, W. D. 2013. Model Konseptual Adaptasi Ruang Kampung Kota sebagai Akibat Keberadaan Sektor Pergadangan Formal (Kampung Sekayu Kota Semarang). Tataloka, 15(2): 140 - 159.

Simonet, G. 2010. The Concept of Adaptation: Interdisciplinary Scope and Involvement in Climate Change. SAPIENS Surveys and Perspectives Integrationg Environment and Society, 3(1): 1 - 9.

Smith, B., \& Wandel, J. 2006. Adaptation, Adaptive Capacity and Vulnerability. Global Environmental Change, 16: 282 - 292.

Saubani, A. 1 April, 2020. Empat Sektor Ekonomi yang Paling Tertekan Pandemi Covid-19. Republika.co.id. https://republika.co.id/berita/q831lp409/empat-sektor-ekonomi-yangpaling-tertekan-pandemi-covid19.

Septalisma, B. 13 April, 2020. Pengamat Sebut 11 Sektor Bisnis Naik Daun Karena Corona. CNN Indonesia. https://www.cnnindonesia.com/ekonomi/20200413184902-92493165/pengamat-sebut-11-sektor-bisnis-naik-daun-karena-corona.

Elvina, L. 12 Maret, 2020. WHO Tetapkan Wabah Virus Corona sebagai Pandemi Global. Kompas TV. https://www.kompas.tv/article/70893/who-tetapkan-wabah-virus-coronasebagai-pandemi-global.

Shiddiq, M. 20 Maret, 2020. Arsitek Indonesia Ingatkan Pengendalian Cahaya dan Udara selama Pandemi COVID-19. Gressnews.com. https://www.gresnews.com/berita/topik_khusus/117872-arsitek-indonesia-ingatkanpengendalian-cahaya-dan-udara-dalam-rumah-selama-pandemi-covid-19.

Menteri Permukiman dan Prasarana Wilayah Republik Indonesia. 2002. Kepmen Kimpraswil Nomor 403/KPTS/M/2002 tentang Pedoman Teknis Pembangunan Rumah Sederhana Sehat (Rs Sehat). Jakarta.

Menteri Kesehatan Republik Indonesia. 2011. Peraturan Menteri Kesehatan RI No. 1077/Menkes/PER/V/2011 tentang Pedoman Penyehatan Udara dalam Rumah. Jakarta.

Marsoyo, A. 2012. Constructing Spatial Capital: Household Adaptation Strategyies in Home Based Enterprises in Yogyakarta. Newcastle: University of Newcastle.

Pamungkas, S. P. 2013. Adaptasi Spasial Tata Ruang Rumah Dome di Dusun Nglepen, Prambanan, Yogyakarta. Yogyakarta: Universitas Negeri Yogyakarta.

Purwono, R. 2 September, 2020. Kajian Adaptasi Disain Arsitektur dan Arsitektur Lanskap dengan Adanya Kehidupan Sosial Baru setelah Pandemi Covid-19. Eprints repository software. http://repository.istn.ac.id/352/.

Rahardjo, M. 31 Januari, 2017. Studi Kasus dalam Penelitian Kualitatif: Konsep dan Prosedurnya. Research Repository. http://repository.uin-malang.ac.id/1104/. 